\title{
ferfings Metke.
}

Ecd) ster Band.

$\mathfrak{s} \mathfrak{t} \mathfrak{t} \mathfrak{t g} \mathfrak{n} \mathfrak{r} \mathfrak{t}$.

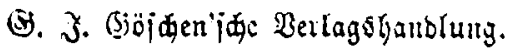

1869. 


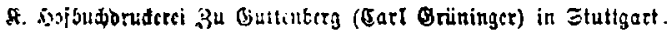

